\title{
Stage III Ampulla of Vater Cancer AJCC v7
}

National Cancer Institute

\section{Source}

National Cancer Institute. Stage III Ampulla of Vater Cancer A/CC v7. NCI Thesaurus.

Code C6653.

Stage III includes: T4, Any N, M0. T4: Tumor invades peripancreatic soft tissues or other adjacent organs or structures other than the pancreas. M0: No distant metastasis. (from AJCC 7th Ed.) 